\title{
Hamlet, or about Death: A Romanian Hamlet directed by Vlad Mugur (2001)
}

\begin{abstract}
This essay looks at the 2001 Romanian production of Hamlet directed by Vlad Mugur at the Cluj National Theatre (Romania) from the perspective of geocriticism and spatial literary studies, analysing the stage space opened in front of the audiences. While the bare stage suggests asceticism and alienation, the production distances the twenty-first century audiences from what might have seemed difficult to understand from their postmodern perspectives. The production abbreviates the topic to its bare essence, just as a map condenses space, in the form of "literary cartography" (Tally 20). There is no room in this production for baroque ornaments and theatrical flourishing; instead, the production explores the exposed depth of human existence. The production is an exploration of theatre and art, of what dramatists and directors can do with artful language, of the theatre as an exploration of human experience and potential. It is about the human condition and the artist's place in the world, about old and new, about life and death, while everything happens on the edge of nothingness. The director's own death before the opening night of the production ties Shakespeare's Hamlet with existential issues in an even deeper way than the play itself allows us to expose.
\end{abstract}

Keywords: geocriticism, Hamlet, Vlad Mugur, Shakespeare production, Shakespeare in Romania, spatial manipulation.

Looking at the cover illustration of Shakespeare Quarterly, representing Arnold Schwarzenegger as Hamlet in John McTiernan's 1993 film Last Action Hero, one cannot help thinking about the unusual elasticity of this play and the possible representations of its hero in intermedial contexts. It has become a commonplace by now to argue that the play's theatrical illustrations serve as a mirror powerfully reflecting contemporary concerns, be they social, political, scientific, or moral. According to what Manfred Pfister has called "the law of diminishing returns" (296), the more information scholars gather concerning

* Ovidius University of Constanta, Romania. 
a certain play or theme in Shakespeare, the less insight is offered into the plays of Shakespeare and his contemporaries. I intend to take a step further along this alienating path of diminishing returns, regarding productions this time, and focus on the director rather than on the increasingly nebulous subject, "Shakespeare," or the even more problematic Hamlet. As William B. Worthen states, the director is perceived as anchoring the slippery text somewhere between "fidelity" and "creativity" (48). Since it is a common fact that the director's understanding of the play's meaning is hermeneutically shifting on a continual basis, this essay follows the virtual adoption of this particular play and its production on a personal level by a Romanian director.

I take this distinct production of Hamlet by Vlad Mugur ${ }^{1}$ as an example of "literary cartography" (Tally 20) - a form of dramatic mapping that has a specific impact on the audiences in different periods because of the spatiality represented on stage in a condensed manner. Robert Tally explains that "adventure stories illustrate and enact the project of narrative mapping by foregrounding in their own aesthetic projects the exploratory, representational, and projective or speculative modes of cartographic theories and practice" (20). Extrapolating this statement from narrative to drama, I see productions of Shakespeare's plays as dramatically re-enacting and re-mapping the specific modes of the production of culture at a certain time, in a certain place, and even by a particular director. Besides exploring, representing and foregrounding the aesthetic characteristics of a specific culture, each Shakespeare production displays the potential to reconstruct-in an abstract manner-the metaphoric space of the play in such a way as the audiences perceive it as if they were in the middle of that particular space. Rather than simply rendering the metaphoric space of the play in different cultures and languages, each particular production re-creates a form of literary cartography in which Shakespeare's and Hamlet's names have become abstractions necessarily attached to the cartographic space of that production. For this reason, I see each Shakespeare production as a form of intermedial literary cartography: the representation moves from the "original" Shakespeare playscript to the first level of abstraction, achieved through the translation in the language of a particular production; then to a second level of abstraction introduced by the director's personal choices in point of setting and

1 The 2001 production of Hamlet, directed by Vlad Mugur at the Cluj National Theatre had the following cast: Hamlet (Sorin Leoveanu); Claudius (Bogdán Zsolt); Polonius, Lord (Anton Tauf); Horatio (Emanuel Petran); Laertes (Radu Brânzaru); Rosencrantz (Stelian Roşian); Guildenstern (Dan Chiorean); Osric (Petre Băcioiu); A Priest (Maria Seleş); Marcellus (Melania Ursu); Player King (Melania Ursu); Player Queen (Miriam Cuibus); Old Player (Ion Marian); Prologue, Lucianus (Ruslan Bârlea); Two Clowns Gravediggers (Miriam Cuibus and Ruslan Bârlea); Fortinbras (Mihai Costiug); Gertrude (Elena Ivanca); Ophelia (Luiza Cocora); Old Hamlet's Ghost (Liviu Matei). 
acting. The theatrical space represented through the newly-devised mapping of a Shakespeare play exposes these levels of abstraction and, as I suggest, a third additional element: personal events in a director's life may be added to the specific mapping in a production.

The appropriation of Hamlet for subversive ideological purposes under communism and after was a common practice among Romanian directors. ${ }^{2}$ Similarly, directors of the 1990s and the 2000s refused to replicate the romantic nineteenth-century interpretations of the hero, except for contrastive representations of theatrical practices. However, Hamlet has never been taken to mean so personally to a director as in this production directed by Vlad Mugur at the Cluj National Theatre in 2001. Mugur knew that he was dying and he chose to direct Hamlet as a final celebration of his artistic activity and a theatrical statement of continuance. Apart from taking over a new interpretation of Hamlet (in 2001) as a remake of his own version of 1971; apart from devising a new Romanian version of the play compiled from various extant translations, plus his own; and, finally, apart from entering his last energies as a director in shaping this production - a kind of Romanian Prospero whose every third thought was his grave-Vlad Mugur remapped the space of Shakespeare's Hamlet in the specific conditions that suited the trajectory of his life. Even the fact that he produced this last swan-song play at the Cluj National Theatre- the place of the first Shakespeare rehearsals during his youth-was an eloquent document in this personal reconfiguring of Shakespeare's emblematic play.

Unusually for Romanian directors and theatres, this particular production is exceptionally documented. There is a documentary book about this production, entitled Vlad Mugur: spectacolul morţii [Vlad Mugur: The Spectacle of Death], edited by Marta Petreu and Ion Vartic (the manager of the Cluj National Theatre), and a video recording of the rehearsals. In a discussion with his assistant director Roxana Croitoru, documented in the book, Vlad Mugur says, "When you have reached my age, you will have known that nothing is for ever! You are not allowed to by-pass Hamlet; it is a chance in a lifetime for you. It is a challenge for me too. I had to do this production" (Mugur qtd. in Petreu and Vartic 143). ${ }^{3}$ In this particular case, we see that "Shakespeare" was needed, not as a banner to legitimise contemporary cultural or political debate, but as an ontological support to justify a director's life dedicated to the theatre. Mugur perceived Hamlet as a self-identifying concept and the existential marker of an aporetical limit. Thus, in this particular case, the true Shakespeare exists, not like a Platonic Ideal Form, as an accepted but ultimately arbitrary hypothesis of no fixed habitation, and not even as an example of what others think Shakespeare

2 For various Shakespeare productions in communist Romania, see Matei-Chesnoiu, Shakespeare in the Romanian Cultural Memory (70-90).

3 All English translations from Romanian are mine. 
is. In Mugur's case, Hamlet comes to represent the vehicle for an individual's intimate relationship with his selfhood, his private existence, and his immediate death. It is as if Hamlet knew he would be dying and he staged the Mousetrap as a symbolic theatrical ceremony of his own death. Who can say it might not be so?

Vlad Mugur (1927-2001) was a Romanian-born director who worked most of his life in the German Theatre. Vlad Mugur's career as a director started in the fifties in Romania, when he directed at the Bucharest, Craiova, and Cluj National Theatres. In 1965 he became the director of the National Theatre in Cluj and he held this position until 1971, when he defected to Italy, and then he went to Munich, Germany. In 1971, when he wanted to direct Hamlet at the Cluj National Theatre, the communist authorities proscribed the rehearsals because the production was too politically revealing and subversively critical of the regime. In a seditious phase, Mugur emigrated to Italy and then to Germany, directing plays produced at the theatres of Munich, Konstanz, Hanover, Esslingen, Münster, and Bern. After the fall of communism in 1989, he returned to Romania and directed plays in Bucharest (The Odeon Theatre), Craiova, and Cluj. In March 2001, at the Cluj National Theatre, in an attempt to bridge a thirty-year gap, Mugur decided to approach Hamlet once more, in a symbolic gesture of theatrical self-reflexivity. The avant-première of this production was on 22 June 2001, on his $74^{\text {th }}$ birthday, and Mugur died exactly one month after that, on 22 July 2001, at his home in Munich. When, in October 2001, the Cluj National Theatre inaugurated the official opening night, the director's presence was only symbolic, a disembodied spirit hovering over an empty seat. He might have appeared as a ghost haunting the theatre, together with Old Hamlet's Ghost, and joined by the ghosts of all Hamlets produced at this theatre and elsewhere, viewed or created by this director or others.

Considering that there is no stable text for his production of Hamlet, Mugur generated a collated script, combining the seven extant Romanian translations and even forging some phrases in his own version. When his assistant director presented him with a revised translation of Hamlet, Prince of Denmark, combined from the extant Romanian translations by Nina Cassian, Ion Vinea, Vladimir Streinu, Leon Leviţchi and Dan Duţescu, Mugur was not completely satisfied with it. Roxana Croitoru admitted she had viewed the Shakespeare text from the philological perspective, focusing on grammatical and lexical accuracy, while the director looked at the scenic script from the theatrical viewpoint. Looking at Hamlet in this light, as Shakespeare might have done, he said he needed to decontaminate the script of all the heavy metaphors, leaving space for the direct theatrical expression and the text's dramatic "nerve" (Mugur qtd. in Petreu and Vartic 109). Mugur said to Roxana Croitoru that he was in need of a more recent translation because the latest one dated from the 1970s and was done by Alexandru Pop especially for Mugur's Hamlet of that time (1971). However, according to the director, that particular translation was 
a romantic Romanian version, and "romantic" productions do not work for audiences these days (Mugur qtd. in Petreu and Vartic 109). Therefore, though the script revised by Mugur was an accurate translation in blank verse, the parts of the Shakespearean play were severely cut and concentrated, so that, at some points, the dramatic exchange takes the form of light repartee. For instance, Polonius' line "For this defect effective comes by cause" $(2: 2: 103)^{4}$ becomes, in Mugur's Romanian script, just “Efect-defect" [Effect-defect] (Mugur 45).

The script mentioned above, in a translation by Vlad Mugur and Roxana Croitoru, is composed of two parts; part one has eight scenes, and part two has seven scenes. The "To be" soliloquy, for instance, is a multiple dialogue initiated by a contemplative character, Lucianus, the Prologue, who acts as Hamlet's alter ego. Positioned at Part 1, scene 6, after Hamlet's "Hecuba" speech, the "to be" exchange was a lesson in reflection and endurance served to a disconcerted Hamlet by Lucianus, Second Player, First Player, Horatio, Guildenstern and Rosencrantz and, ultimately, Polonius. As in a sophisticated golf game-and golf was another hidden theme suggesting psychological tension and releasethese characters took over the stroke-play in turn. They informed Hamlet of the potentially lethal dimension of human existence, of the dangers of to die, to sleep, and the undiscover'd country from whose bourn no traveller returns. The Players' intimations about death were friendly, almost parental, spoken in a soft voice, and they were read from the production's play script. The shuffled pages suggested the transition from play-text and script to actor, director and, finally, theatrical performance. Moreover, the First Player who spoke these weighty verses (Melania Ursu, an actress) was wearing a nondescript raincoat, as most characters associated with Hamlet did, but this particular player sported the long white scarf that had come to symbolise the director's distinctive costume as a theatrical prop. While the actor-director-substitute in the play lectured Hamlet about death, sustained by a variety of actors interpreting other characters in the play, and while Hamlet played the director in staging the Mousetrap, the real-life director, Vlad Mugur, staged a representative Shakespeare play that anticipated symbolically his own death.

The sets were a construction site, a world that was being built and rebuilt continuously before the audience's eyes. This was the only symbolic section in the production that might be interpreted as having a contemporary cultural and political connotation, since Romania in the transition phase of the 1990s was a place where old institutions had been demolished and many were under construction. At the beginning of the play, the curtain was up and some actors were among the audience. The first scenes were played against a white screen (suggesting all possible film adaptations of Hamlet) and the actors were

\footnotetext{
${ }^{4}$ References to Hamlet are to the Arden Shakespeare, edited by Harold Jenkins (1993).
} 
sitting at a long table on stage, reading their parts from the play script. The Shakespeare text was conceived initially as the blank reading of a script and the director saw this activity as a form of therapy with the audience, to whom an important message was being communicated (Mugur qtd. in Petreu and Vartic 113). At one moment during the production, however, after the ghost scene, the script matured into performance: the written text became theatre. Before this crucial moment, the actors had been on stage or among the audience as actors interpreting a script. The reading came alive gradually, as the actors became characters in performance, an action triggered by the Ghost's entrance.

The Ghost's apparition was the ghoulish image of a semi-decomposed cadaver, whose head exposed a strange system of pipes, revealing an outlandish human anatomy. Old Hamlet's ghost appeared from a construction scaffolding on the left of the stage, emerging in a cloud of plaster debris, cement dust, and fumes, and exited through an improvised workers' elevator within the same structure. Everything is under construction, in real life and in the world of the play, and each character is reclaiming another Eden. Cement, dust and lime were the main symbols in this production, and Mugur said that the white powder was almost as dramatically suggestive as blood because it assaulted the audience's senses, irritating their nostrils and throat, and making them feel empathy with Hamlet's drama. Indeed, when sitting in the first row (as I did when experiencing this production in February 2002), the stingy smell of cement dust was really irritating and I felt revolted at this aggressive mise-en-scène. I even started coughing because of so much cement dust, which reminded me of the ordeals suffered during the process of having recently renovated my apartment. Thus, the experience of my life was added to the tragedy of Hamlet's history.

In the rehearsal notes, Mugur said he would not focus on the philosophical aspect of the play because, in any case, the tragedy breathed metaphysically and the contemplative area was evident (Mugur, qtd. in Petreu and Vartic 119). Moreover, the director wanted to avoid the temptation of producing the play in the romantic-philosophical mode and thus he focused on the "situations" (Mugur, qtd. in Petreu and Vartic 120). As regards the text, this situation-oriented form of acting needed to preserve the rhythm of the verse, its cadence, and not its fluency. Therefore, the actors were instructed to act the script by breaking the verse into short utterable units, thus departing from iambic pentameter verse. By avoiding the cadence of the original verse-form, Mugur said, the actors would learn to circumvent the text and evade the risk of giving the impression that they were over-dramatizing an obsolete spectacle in the romanticised mode. This "running away from the traditional verse-form" (Mugur, qtd. in Petreu and Vartic 121) was, in Mugur's perception, a valid means of asserting the spectacle's modernity, by showing a break with the convention of the romantic-mode interpretation of Hamlet. Mugur has coined the traditional declamatory interpretation of former times as "tăirist" (Mugur, qtd. in 
Petreu and Vartic 126), ${ }^{5}$ a term that suggests the notion of larger-than-life acting meant to impress the audience with emphatic tones. By contrast, his Hamlet (Sorin Leoveanu) spoke with the intimacy of normal conversational flow but had the effect to hit the audience in the solar plexus.

The space of the stage was of maximum ascesis, the "bare stage" (Ichicawa 86) of the public playhouse in the original staging of plays by Shakespeare and his contemporaries, as documented by Mariko Ichicawa in The Shakespearean Stage Space (2013). Ichicawa focuses on "the relation between onstage and offstage spaces and on the audience's awareness both of the imaginative world created by the play and the wood, lath and plaster reality of the playhouse itself - that is to say, the balance between fiction and the theatre" (Ichicawa 1). This is similar to the abstract space of the The Tempest, in which the bare island symbolized the bare stage, which was then gradually peopled by characters created by the actor/playwright/stage manager; this production's director was, like Prospero, managing everything and making exciting things happen. In this Romanian production, however, we were in the baroque-style National Theatre of the Romanian city of Cluj-Napoca, with its red-velvet seats and carpeting and the gilded-plaster ornaments on the balconies. However, the red plush carpets were covered with dirty plastic foils reeking of paint, so the impression of an unfinished project-in-the-making was overwhelming, though disagreeable. These are the trappings of creation - in playwrighting as well as in directing - when the unfinished business of the theatre must pass through intermediate stages of refashioning before it becomes the apparently coherent object that we think we have: the playscript. Yet this seemingly completed artefact is in continual rehearsal, until what we think to be the finished production emerges.

The nunnery scene was a dynamic duo exchange in which Hamlet played the aggressive ego trying to subdue the girlish Ophelia, who had just discarded her virginity veil and tutu ballet skirt and tried to defend herself from Hamlet's dart-words. The tutu symbolized the romantic theatrical interpretations of Ophelia and her innocence, while in this scene she discarded these romantic appropriations and lay frightened and defenceless among the debris of the construction site. Ophelia also lay prone among the scattered pages of the playscript, while the book from which Hamlet had been reading his "Words, words, words" (2:2:192) was the much-annotated play-text of Hamlet, marked

5 "Trăirism" [philosophy of living] was an inter-war literary trend in Romanian criticism, mainly promoted by philosopher Nicolae C. Ionescu (1890-1940), which professed an attitude inspired by the so-called "life philosophy" (from philosophers such as Kierkegaard, Nietzsche, Spengler, Bergson, etc.). The critical trend focused on proclaiming the primacy of living over the intellect. The term was coined by Romanian critic Şerban Cioculescu, who translated from German the term "Lebensphilosophie" (philosophy of living) (Călinescu 915; 953). 
with yellow sticky notes at the significant passages (probably the actor's annotations for the role of Hamlet). This self-reflexivity highlighted, once more, the transition from the so-called "Shakespeare" text and the infinite variants of its production, as manifested through acting and directing. The ladders and incomplete scaffolding in the background created the unfinished and potential space of performance, while the two classically-designed columns on the left of the stage reminded that the book about the "satirical rogue" (2:2:196) that Hamlet was reading might have been the Greek philosopher Aristotle, or the Latin poet Horace, or none of them. Yet all could see that Hamlet's audacity and cynical philosophy was rooted in classical thought.

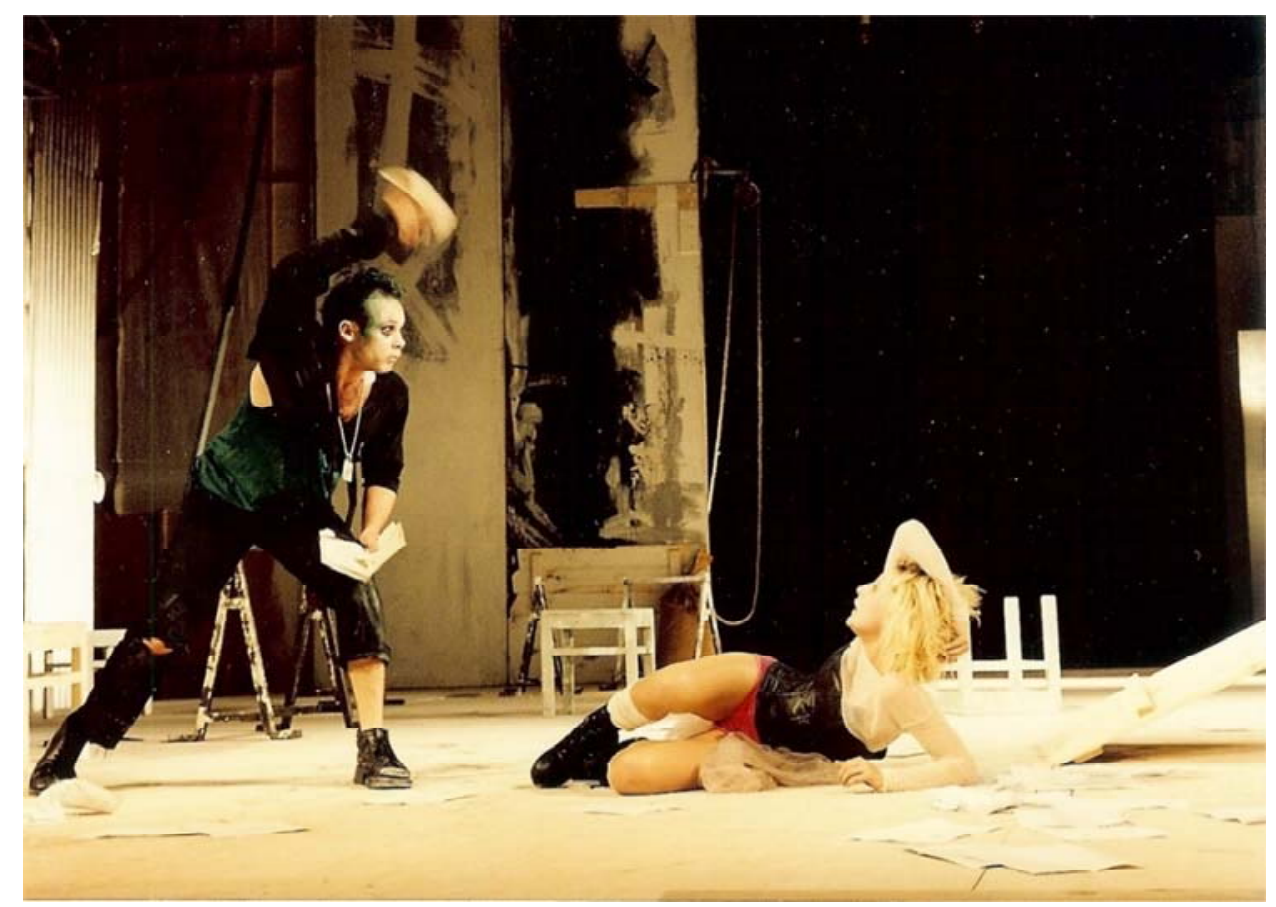

Sorin Leoveanu as Hamlet and Luiza Cocora as Ophelia in the 2001 Production of Hamlet directed by Vlad Mugur at the Cluj National Theatre.

Photo Nicu Cherciu, Réel Photo Agency. Printed by permission of the author.

In distinguishing between text and performance and showing how the script was turned into theatre, Mugur warned about the hybrid nature of drama, which since the nineteenth century had created inconclusive debates in the separate fields of performance and text, viewed in an intermedial context. Through this production, Vlad Mugur indirectly commented on how Shakespeare was evoked to authorise the critic, or the director, or received notions of theatrical practice. According to his notes, Mugur wanted audiences 
to infer from this spectacle the state of alienating insanity we would all reach if confronted with exceptional circumstances, blurring the border between normality and the pathological. The basic premise in this production was no longer that of the author at work, but that each theatrical text was always already contextually (re)constructed. Mugur's production of Hamlet discriminated between page- and stage-views of the play, each claiming a unique fidelity to the elusive "Shakespeare," whose plays had been reconfigured in various media. Mugur exploded the naïveté of both views, which were misleading for readers and audiences alike. There is no clear answer as to Mugur's response regarding the validity of one view or another, but the explanation lies in the director's choice of the author and play. In choosing Shakespeare and Hamlet ${ }^{6}$ as the ultimate theatrical statement of a lifetime dedicated to the stage, Mugur deftly choreographed the semantic slippage that resulted from all these definitions and re-definitions of what others thought Shakespeare was. He tied up the dialogic uncertainty with a final conclusive category: death, his own. Like life and the theatre, death just is.

\section{WORKS CITED}

Călinescu, George. "Nae Ionescu." Istoria literaturii române de la origini pînă în prezent. Bucureşti: Editura Minerva, 1982. 953-954.

__. "Şerban Cioculescu." Istoria literaturii române de la origini pînă în prezent. Bucureşti: Editura Minerva, 1982. 914-915.

Constantinescu, Marina. "Hamlet sau despre moarte." România Literară 27 (2001). https://arhiva.romlit.ro/index.pl/hamlet_sau_despre_moarte. 31 July 2019.

Cover illustration to Shakespeare Quarterly 50 (Summer 1999). Arnold Schwarzenegger as Hamlet in John McTiernan's 1993 film Last Action Hero. Movie adaptation written by Zach Penn and Adam Leff. With Arnold Schwarzenegger, F. Murray Abraham, Art Carney. Columbia Pictures, Oak Productions, 1993.

Horasganian, Bedros. "Julieta, Ofelia, Romeo şi Hamlet." Observator cultural 93 (December 2001). https://www.observatorcultural.ro/articol/julieta-ofelia-romeosi-hamlet/. 31 July 2019.

Ichicawa, Mariko. The Shakespearean Stage Space. Cambridge: Cambridge University Press, 2013.

Matei-Chesnoiu, Monica. Shakespeare in the Romanian Cultural Memory. With a Foreword by Arthur F. Kinney. Madison, Teaneck: Fairleigh Dickinson University Press, 2006.

${ }^{6}$ For online Romanian reviews of this production of Hamlet see Marina Constantinescu, "Hamlet sau despre moarte," România Literară 27 (2001), https://arhiva.romlit.ro/ index.pl/hamlet_sau_despre_moarte; Bedros Horasganian, "Julieta, Ofelia, Romeo şi Hamlet," Observator culturä 93 (December 2001), https://www.observatorcultural.ro/ articol/julieta-ofelia-romeo-si-hamlet/. 
Mugur, Vlad. "William Shakespeare. Tragedia lui Hamlet, Prinţ de Danemarca. Versiune regizorală de Vlad Mugur." In Vlad Mugur, spectacolul Morţii. Ed. Magda Petreu and Ion Vartic. Cluj Napoca: Biblioteca Apostrof, Teatrul National Cluj, 2001. 45-88.

Petreu, Magda and Ion Vartic, eds. Vlad Mugur: spectacolul morţii [Vlad Mugur: The Spectacle of Death]. Cluj Napoca: Biblioteca Apostrof, Teatrul National Cluj, 2001.

Pfister, Manfred. "Shakespeare and Italy, or, the Law of Diminishing Returns." Shakespeare's Italy. Functions of Italian Locations in English Renaissance Drama. Ed. Michele Marrapodi, A. J. Hoenselaars, Marcello Capuzzo, and L. Falzon Santucci. Manchester: Manchester University Press, 1993. 295-303.

Shakespeare, William. Hamlet. The Arden Shakespeare. Third Series. Ed. Harold Jenkins. $5^{\text {th }}$ ed. London: Routledge, 1993.

Tally, Robert T. Jr. "Adventures in Literary Cartography: Explorations, Representations, Projections." In Literature and Geography: The Writing of Space throughout History. Ed. Emmanuelle Peraldo. Newcastle-upon-Tyne: Cambridge Scholars Publishing, 2016. 20-36.

Worthen, William B. Shakespeare and the Authority of Performance. Cambridge: Cambridge University Press, 1997. 